\title{
Effect of Participative Budgeting, Organizational Commitment and Work Motivation on Managerial Performance (Survey of Motor Vehicle Dealers in Bandung)
}

\author{
Syakieb Arsalan*, Mohd Haizam Mohd Saudi, Rini Susiani, Acep Adison \\ Faculty of Economics, Widyatama University, Bandung, Indonesia \\ *Corresponding author E-mail: syakieb.arsalan@widyatama.ac.id
}

\begin{abstract}
This research is aimed to find out the influence between participative budget, organization commitment and work motivation on the managerial performance of some automotive dealers in Bandung West Java. The method used in this research is empirical research through a mail survey. Data collection was conducted by using questionnaires in which Likert scale is used as the basis. The questionnaires were spread to 179 Dealer managers. The data which were collected, later on, were managed and were analyzed by using dual regression analysis (Multiple regression analysis) through the SPSS program. The result of this research shows that the participative budget, organization commitment, and work motivation give a positive influence on managerial performance. The significant influence of Participative Budget and Organization Commitment partially are about 0,044 and 0,000. The significant influence of Work Motivation on managerial performance partially is about 0,098 . The significant influence of participative budget, organization commitment, and work motivation on managerial performance simultaneously are 0,000. It means that partially participative budget and organization commitment give significant positive influence on managerial performance, while work motivation gives insignificant positive influence on managerial performance. Simultaneously, participative budget, organization commitment, and work motivation give significant positive influence on managerial performance.
\end{abstract}

Keywords: Participative Budget; Organization Commitment; Work Motivation and Managerial Performance.

\section{Introduction}

The number of cars and motorbikes in Bandung continues to increase day by day. Vehicles circulating in the city of Bandung are increasingly and more diverse in line with the development of the needs and development of consumer tastes. Dealers as agents that distribute automotive products to the hands of end consumers contribute to the increase in circulating vehicles. The rapid increase in the number of vehicles circulating attracts the attention of the authors to examine the parties that play a role in car sales, especially in the city of Bandung, and want to process empirical information about the effects of participatory budgeting, organiza- tional commitment and work motivation on operational performance.

Vehicle sales involve Brand Holder Agents (APM) as producers, along with agents or Dealers that function to channel vehicles to the end consumers.

Dealer profits reflect the performance of its managers, measured primarily by the sale of vehicle units in addition to the sale of spare parts, service shops, and the number of units that can be serviced for annual maintenance according to the target.

Data obtained from 2013 to 2017 realization of unit sales of 5 car brands with the most sales on a national scale by APM through the dealers as follows:

Table 1: Total sales of vehicles

\begin{tabular}{|c|c|c|c|c|c|c|}
\hline \multirow{3}{*}{ No. } & \multirow{3}{*}{ Vehicle Dealers } & \multicolumn{5}{|c|}{ Sales Per Unit } \\
\hline & & 2013 & 2014 & 2015 & 2016 & 2017 \\
\hline & & Sales & Sales & Sales & Sales & Sales \\
\hline 1 & Toyota Astra Motor (TAM) & 186.687 & 280,680 & 310,674 & 405,414 & 434,232 \\
\hline 2 & Astra Daihatsu Motor (ADM) & 77.523 & 118,591 & 139,544 & 162,742 & 185,942 \\
\hline 3 & Krama Yudha Tiga Berlian (KTB) & 61.735 & 106,483 & 134,416 & 148,918 & 157,353 \\
\hline 4 & Suzuki Indomobil Sales (SIS) & 44.689 & 71,210 & 94,569 & 126,577 & 164,004 \\
\hline 5 & Honda Prospect Motor (HPM) & 39.670 & 45,416 & 61,336 & 69,320 & 91,493 \\
\hline & Total & $1,033,024$ & 410.304 & 622,380 & 622,380 & 912,971 \\
\hline & Target & $1,208,211$ & 464,816 & 702,508 & 702,508 & $1,065,557$ \\
\hline & Percentage of Sales & $86 \%$ & 2013 & 2014 & $89 \%$ & $86 \%$ \\
\hline
\end{tabular}

The table above shows that although from year to year shows an increase in sales targets from 2013 to 2017 , there is always a difference between the target and the results achieved. The number of car sales never reaches the desired target. For Dealers, the number of sales is one form of organizational commitment and managers to achieve company goals. Planning budget costs and 
predetermined sales targets should motivate Dealer managers to achieve targets and increase Dealer revenue.

In accordance with the characteristics of the budget, participation in the preparation and implementation of the budget is a commitment, as well as motivating participants to implement and achieve organizational goals. Strong organizational commitment in the individual has an impact on the individual's hard efforts to achieve organizational goals and generate a willingness to work on behalf of the organization to improve performance [8]. These commitments and motivations are organizational commitment and manager's motivation to achieve managerial performance. This success will, in turn, be the success in achieving the goal of the Dealer in carrying out the vision, mission, and goals of the company that has been set.

Researchers suspect that the increase in Dealer income as a result of improving managerial performance which is influenced by supervisor's policies towards subordinates, especially concerning subordinate involvement in terms of budgeting, organizational commitment, and motivation.

\section{Literature Review}

\subsection{Budget}

The company budget is defined as follows: In [5] define that a budget plan is detailed, expressed in quantitative terms that specifies how organizations will acquire and use resources during a particular period of time. The procedures used to develop a budget constitute a budgeting system.

The budget is a formal and systematic statement regarding future action plans proposed in detail by management. The preparation is carried out on the basis of a certain number of assumptions for activities to be carried out, and measured in monetary units and other units. The budget shows the acquisition and use of sources of an organization and will be used as a guide for the implementation of activities within a certain period, usually one year.

If a budget is too ideal and difficult to achieve, it will cause the unwillingness of the budget maker to achieve it. Conversely, if a budget is too easy to achieve, it also lacks challenges, stimuli, or less motivates the budget builder to achieve. Budget builders will try to avoid variants that are too large because it might lead to heavier tasks for the following year [2].

\subsection{Participatory Budgeting}

According to [4], participatory budgeting is a process in which individuals are involved in it and have an influence on the preparation of budget targets to be evaluated, and according to Kennis Budget Participation is the level of participation of managers in preparing budgets.

People involved in decision making will better understand, accept decisions, and feel bound to a decision. After ensuring that budgetary support is sufficient to carry out their duties, then they wish to carry out the task. This is most likely to improve the close relationship between participants with organizational commitment so that it will affect their performance.

Manager's participation in budgeting will lead to initiatives for them to contribute ideas and information, increase togetherness and feel ownership, so that cooperation among members in achieving goals also increases.

\subsection{Organizational Commitment}

According to [3], organizational commitment has three components: (1) Affective Commitment, shows the strength of a person's desire for an emotional event to identify himself with the values and goals and the desire to remain a member to achieve that goal Matters that lead to effective commitment include individual characteristics, organizational structure characteristics, task significance, various skills, feedback from leaders, and involvement in management. (2) Continuance Commitment, is a commitment based on the costs borne by the employee when they leave the organization; Continuance Commitment is a commitment based on one's concern about losing something that has been obtained from the organization so far, such as position, salary, facilities and others and (3) Normative Commitment, is a feeling that indicates that employees are obliged to stay or be in the organization. The emergence of this commitment results in the existence of social demands which are the result of one's experience in interacting with others (affiliating) or the emergence of constant obedience to someone who has an organization because of services, social, cultural or religious, gets special training and skills improvement.

\subsection{Work Motivation}

According to [9], motivation is the result of the interaction of the individual and the situation. Whereas, according to [7], motivation is a desire in a person that causes the person to take action.

Every activity carried out by a person is driven by a power from within and from the outside of the person. This driving force is called motivation that exists in someone who will realize a behavior that is directed at the goal in order to achieve the ultimate goal of performance. Motivation is the process of giving encouragement to subordinates so that subordinates can work in line with the limits given in order to achieve organizational goals optimally, understanding the process of providing encouragement is a series of activities that must be passed or done to foster encouragement to employees to work in line with organizational goals. This opinion was expressed by [10].

\section{Methodology}

\subsection{Object of Research}

Objects in this study are Participatory Budgeting, Organizational Commitment, and Work Motivation. This research was conducted at several dealers of motorized vehicle brands in Bandung. As an analyst unit in this study is the manager and chief manager of the manager. The reason for choosing this unit of analysis is because the managerial performance of Dealer managers has not been able to support the achievement of the revenue targets set out in the Company Business Plan. This study was designed as an empirical study using all members of the population of 176 managers from five Motor Vehicle Dealer Brands in Bandung.

\subsection{Research Methods}

In this study, the method used is an explanatory research method using a survey approach which is a field research conducted on several sample members of a particular population whose data collection is done using a questionnaire. The type of data in this study researcher obtained from primary data. Data collection uses analytical methods conducted by questionnaire. The collection of data contained in the variables is developed in the form of written questions which are then given to the respondent. Questions consisting of general questions and special questions are submitted directly and delivered to the Dealer address in Bandung. Respondents were asked to give an assessment by choosing one from 1 to 7 Likert scale.

\subsection{Variable Operations and Variable Indicators}

\subsubsection{Participatory Budgeting}

Participation budgeting is an independent variable. In this study, it is determined by the presence or absence of the manager's right to submit a budget proposal and the right to approve or reject the decision-making process and set a budget. Participation in budgeting is the level of involvement and influence of individuals in the budget preparation process which in this case is stated with indicators of the right to submit a budget proposal, while influence is stated with the right to approve or reject the budget set. To meas- 
ure the extent to which the high and low participation of managers in the preparation of the budget at the responsibility center they lead, a question consisting of 6 items is used.

\subsubsection{Organizational Commitment}

Organizational commitment is an independent variable. In this study, organizational commitment is a strong desire to maintain itself in the organization and is willing to make high efforts for the achievement of the organization. In this study, the high and low level of organizational commitment was examined with three indicators namely there are a desire and attachment to be part of the organization and achievement, the need to stay in the organization because it needs it and feel obliged and important to remain loyal to the organization. To measure organizational commitment, variables used questions consisting of 9 items.

\subsubsection{Motivation}

Motivation is an independent variable which is predicted to affect the implementation of the activities of the responsibility center that he leads. Motivation indicators in this study include three needs according to McClelland namely Achievement Needs, Affiliate Needs, and Power Needs. To measure the level of work motivation, the Motivation variable, the respondents were asked 15 items.

\subsubsection{Managerial Performance}

Managerial performance is the dependent variable. It is the result achieved by the manager in management activities which include (1) Planning; (2) Investigation; (3) Coordinating; (4) Evaluation; (5) Supervision; (6) Staff Selection; (7) Negotiations; (8) Representative. Managerial activity is a measurement indicator of managerial performance and low, using a list of questions adopted by [6] as many as 8 questions.

\subsubsection{Types and Sources of Research Data}

The data that the author will use in this study is subject data. Subject data is a type of research data in the form of opinions, attitudes, experiences or characteristics of a person or group of people who are the subject of the study (respondents). While, the data source that the author will use in this study is primary data. Primary data is the main data that the author will use in completing this research, which is obtained directly from the original source (not through intermediaries). Primary data is obtained through surveys of respondents, by distributing questionnaires to related parties.

\subsubsection{Data Collection Procedure}

The data to be collected in this study include data on Participatory Budgeting, Organizational Commitment, Work Motivation and Managerial Performance of Motorized Vehicle Dealers in 2017. The data that has been collected will be scored according to the established indicators.

The population selected in this study were individuals who held the positions of branch heads, sales department heads, workshop heads, and motor vehicle parts dealers, Toyota, Daihatsu, Mitsubishi, Suzuki, and Honda heads in Bandung. This study focuses on dealer managers, who are usually actively involved and responsible for budgeting for the part they lead.

The criteria of respondents selected in this study are the manager of the dealer, or the head of the manager level and has a supervisor and subordinate, is responsible for the preparation and use of the budget, with the consideration that the manager or manager-level manager who works in the company, is expected to respond to the questionnaire sent.
The questionnaire sent has valid and reliable criteria. It is said to be valid and reliable if it is able to measure what you want to measure even if it is used many times it will give consistent results.

Validity test is done to test whether the measuring instrument that has been prepared can really measure what is being measured (accuracy). Reliability tests are carried out on valid questions to determine the extent to which the measurement results remain consistent if a measurement is made of the same symptoms. Reliability is more directed to the standard level of a research instrument. Reliability means reliable or reliable.

After the data obtained and assessed are feasible in terms of validity and reliability, then the data is processed and analyzed with Multiple Regression.

\subsubsection{Analysis Procedure}

The analytical procedure in this study is as follows: (1) Calculating the value of the dependent variable Manager's Performance. (2) Calculate the number of independent variable values Participatory Budgeting, Organizational Commitment, and Work Motivation. (3) The analysis in research using Multiple Regression methods.

\section{Results and Analysis}

\subsection{Research Result}

\subsubsection{Overview of the Observation Unit}

The research observation unit is a private company engaged in the sale of units, spare parts, and the sale of motor vehicle service services. The company has the right to officially run its business from a Brand Holder Agent (APM). The company called the motor vehicle dealer is an extension of the APM of Toyota, Daihatsu, Mitsubishi, Suzuki, and Honda. Motor vehicle dealers are business entities established based on Notarial Deeds as a profit-oriented company.

As the unit of analysis in this study is the Manager consisting of the branch heads, the head of the vehicle sales department (showroom), the head of the workshop, and the head of the spare parts section. Mentioning the names of positions in each Dealer may be different, but judging from the functions and responsibilities are the same or have many similarities in the level of the Manager. The total population of 176 managers.

\subsubsection{Descriptive Analysis of Respondent Characteristics}

Male employees are more dominating because in addition to business fields that tend to be more attractive to male employees, the company management may have its own view that the reality proves that employees who are much needed for dealers are men who are considered more adaptable to perform tasks field assignment.

The majority of Bandung Dealer Managers are aged 31-35 years and of course with that age shows that the managers of this company are classified as young people who are very productive and have high enthusiasm which is expected to produce a good performance for the company. The majority of them have the last degree. With a majority of at least an S1 background, the company obtains a workforce with a high standard of education and is expected to be burdened or able to work with jobs at the Dealer.

Managers at Bandung Dealers who respond to this research are mostly or the majority are Parts Heads who are one of the business units in each Dealer and support the Dealer's business activities as a whole through the purchase and sale of spare parts as well as meeting the needs of its own workshop. Managers of most Managers at Bandung Dealers have a working period of 6-10 years. 
With the majority of the working period, these managers are expected to have sufficient experience to understand and understand the situation in the business environment in carrying out their functions and responsibilities as managers.

\subsection{Validity Analysis}

\subsubsection{Managerial Performance Validity Analysis}

Testing the validity and reliability of 108 respondents is known that all items (9 items) from the Manager Performance variable get a correlation coefficient greater than 0.189 ( $\mathrm{r}_{\text {table}) \text {, which identifies }}$ that the research instrument on Manager Performance is valid based on the criteria of the alpha coefficient. Valid i.e. the instrument (questionnaire) used is able to measure the Manager's Performance.

\subsubsection{Validity Analysis of Participatory Budgeting}

Testing the validity and reliability of Participatory Budgeting was measured and analyzed with 6 items of questions on 108 respondents. It was known that all items (6 items) of the Participatory Budgeting variable received a correlation coefficient greater than rtabel which identified that the research instrument on Participatory Budgeting was valid based on criteria of the alpha coefficient. Valid i.e. the instrument (questionnaire) used is able to measure Participatory Budgeting.

\subsubsection{Validity Analysis of Organizational Commitments}

Testing the validity and reliability of Organizational Commitment was measured and analyzed by 9 items of questions on 108 respondents. It was known that all items (9 items) from the Organizational Commitment variable got a correlation coefficient greater than 0.189 ( $\left.\mathrm{r}_{\text {table }}\right)$, which identified that research instrument on Organizational Commitment is valid based on the criteria of the alpha coefficient. Valid i.e. the instrument (questionnaire) used is able to measure the Organizational Commitment

\subsubsection{Analysis of Work Motivation Validity}

Testing the validity and reliability is measured and analyzed with 15 items of questions on 108 respondents. It is known that all items (15 items) from the Work Motivation variable got a correlation coefficient greater than $0.189\left(\mathrm{r}_{\text {tabel }}\right)$, which identifies that the research instrument on Work Motivation is valid based on the criteria of the alpha coefficient. Valid i.e. the instrument (questionnaire) used is able to measure Work Motivation.

\subsection{Reliability Analysis}

\subsubsection{Participatory Budgeting Reliability Analysis}

Based on the results of the reliability test, the output of the product quality variables obtained from the 6 statements obtained by Cronbach's alpha results from $0.829>0.60$ means that the Participatory Budgeting variable is reliable, i.e. the instrument (questionnaire) used to measure Participatory Budgeting produces a consistent measure even though it is used to measure many times.

\subsubsection{Organizational Commitment Reliability Analysis}

Based on the results of the reliability test, the output of the product quality variable from the 9 statements obtained by Cronbach's alpha is $0.871>0.60$ which means that the Organizational Commitment variable is reliable that is the instrument (questionnaire) used to measure Organizational Commitment produces a consistent measure even though it is used to measure many times.

\subsubsection{Motivation Reliability Analysis}

Based on the reliability test results, the results of the product quality variable obtained from the 15 statements obtained by
Cronbach's alpha result from $0.971>0.60$ means that the Work Motivation variable is reliable that is the instrument (questionnaire) used to measure Work Motivation produces a consistent measure even though it is used to measure many times.

\section{Discussion}

\subsection{Influence of participant budgeting on managerial performance}

Participatory Budgeting has a significant positive effect on Managerial Performance. The results of processing the answers to the questionnaire data show that $50.98 \%$ of the managers who were respondents were already involved in the budget preparation process for each of their accountability centers. Thus, it can be said that the greater the involvement of managers in Participatory Budgeting will have a positive and greater impact on improving Managerial Performance on motor vehicle dealers in Bandung.

This study shows that there are other factors that can affect managerial performance that need to be considered. Participatory budgeting will get the attention of managers if participatory budgeting is meaningful to managers in achieving their performance. The implication of the results of this study is that participatory budgeting must be able to reflect activities that are beneficial for measuring managerial performance.

\subsection{Effect of Organizational Commitment to Manageri- al Performance}

Organizational commitment has a positive influence on Managerial Performance in this study. The regression coefficient of Organizational Commitment is 8.884 with a significance level of 0.00 which means that the Organizational Commitment in this study has a positive effect on managerial performance. Managerial performance reflects the organizational commitment of managers to motor vehicle dealers in Bandung.

The results of the data processing of the respondents' questionnaire answers obtained results that amounted to $49.30 \%$ of the respondent managers at the Bandung Dealer approve organizational commitment or in other words have carried out their organizational commitment.

In this study, there were respondents who said they did not agree to be in the highest position $(19.4 \%)$. This indicates a practice that has not been satisfactory for managers that the desired results are in accordance with agreed commitments within the organization and those related to parties outside the organization. In other words that organizational commitment is made, but the implementation is not in accordance with the expected goals.

\subsection{Effect of Work Motivation on Manager Perfor- mance}

From the results of processing the data answers to the questionnaire, respondents obtained results that $50.12 \%$ of the respondent managers at the Bandung Dealer showed a statement of having motivation under doubt. The results of the questionnaire showed the highest number of $17.72 \%$ as many as 19 respondent managers under hesitation agreed to the statement about motivation. Overall, the statement agrees to motivation is only $49.88 \%$ or in other words, Managerial Performance does not reflect the manager's work motivation in achieving it.

But, the results of testing the influence of Motivation on Manager's Performance shows that the achievement of the manager's performance needs to consider the strengths or needs that can affect the wishes of the managers whose performance will be measured. 
The test results show motivation is not something that is independent, motivation has a positive but insignificant influence refers to the needs of managers who are not fulfilled. In the need for achievement, obtained results that managers are not serious enough to improve their performance in the past because they think whether or not the planned target is achieved has little effect on the assessment of the achievements they have received, they also do not want to know how they progress when completing the task. They also do not enjoy the satisfaction of working on difficult tasks and assume that the level of difficulty of the work they face does not affect the level of reward they receive. In the need for power, managers do not enjoy competition and victory with responsibilities imposed on them and do not try to influence others to follow their ways to get more control over the tasks they do. In the affiliate needs section, the results obtained are dominated by a lack of communication with other people about things outside of work, emotional bonding with the company and cooperation with others.

\subsection{Effect of Participatory Budgeting, Organizational Commitment, and Work Motivation, on Simultaneous Managerial Performance}

The results of the fourth hypothesis test indicate that the value of $F_{\text {count }} 29.438$ is greater than the value of $F_{\text {table }} 3.08$, and the significance of $F_{\text {count }}$ is 0.00 smaller than $F_{\text {table }} 0.05$. The results of the hypothesis testing show that participatory budgeting, organizational commitment, and work motivation simultaneously have a significant positive influence on managerial performance. Implementation of Participatory Budgeting, Organizational Commitment, and work motivation simultaneously will provide support for managers to achieve their performance.

\section{Conclusion}

\subsection{Conclusion}

1. Participatory budgeting carried out by dealers in Bandung has an influence on the achievement of managerial performance, the greater the involvement of executing managers in the budget preparation process, the managerial performance of the managers of motorized vehicle dealers will be better.

2. The organizational commitment that is exposed by Dealers in Bandung has an influence on the achievement of managerial performance the stronger the commitment made by executing managers, the better managerial performance of motor vehicle dealers will result.

3. Motivation Managers who work at the Bandung Dealer have an influence on the achievement of managerial performance the greater the work motivation of the executing managers, the better managerial performance of motor vehicle dealer managers.

4. Participatory budgeting, organizational commitment, work motivation, which is carried out simultaneously will have a positive impact on the managerial performance of motor vehicle dealers in Bandung

\subsection{Suggestions}

1. Participatory Budgeting, Commitment and Work Motivation

a) Dealer managers should include subordinates (bottom-up approach) to participate in budget preparation until final (final) decision making in accordance with their fields and try to consider the contributions of managers in providing input on the budget that is arranged, so that managers feel much of their influence reflected in the final budget.

b) We recommend that companies always strive so that managers remain committed and remain loyal to the company. The willingness of managers who agree to accept any assignment to continue working in the organization and feel happy choosing an organization where they work now rather than another organization deserves to be appreciated so that they have a sense of pride in their organization.

c) Give a role in preparing and evaluating the budget so that it can encourage managers to be motivated to excel despite facing difficult challenges. Provide motivation for power needs that are needed as part of their managerial functions. Provide an understanding of the need for affiliates so that managers realize that in addition to competitive conditions, carrying out duties in a friendly environment and obtaining inner satisfaction is also a factor that supports the achievement of high performance.

\section{Managerial Performance}

a) We recommend that managers always be involved in the preparation of corporate strategies and business units they lead so that managers feel committed to the company and motivated to carry it out with all their heart, trust the budget, and feel responsible for carrying it out.

b) Dealer managers should strive to be more careful in preparing and achieving the targets set out in the Business Plan; Attempting to carry out tasks and achieve performance proactively, communicate effectively with subordinates, collect, receive, information that is sourced from internal and external sources that are more accurate and accurate, and process and analyze it. Internal information can be sourced either from subordinates, lower level managers, or top-level managers. Both in the same field and with field managers who are related to the field of responsibility. External information, for example, relates to the policy of the Brand Holder Agent.

\section{References}

[1] Adrianto, Y., 2008. Analisis Pengaruh Partisipasi Penyusunan Anggaran Terhadap Kinerja Manajerial Dengan Kepuasan Kerja, Job Relevant Information Dan Motivasi Kerja Sebagai Variabel Moderating. Master thesis, Universitas Diponegoro.

[2] Anthony, R., \& Vijay, G., 2007. Management Control Systems. McGraw-Hill.

[3] Asriningati., 2006. Pengaruh Komitmen Organisasi Dan Ketidakpastian lingkungan Terhadap Hubungan Antara Partisipasi Anggaran Dengan Senjangan Anggaran (Studi Kasus Pada Perguruan Tinggi Swasta Di Daerah IstimewaYogyakarta). Master thesis.,Universitas Islam Indonesia.

[4] Brownell, P., 1982. Participation in the Budgeting Process-When It Works and When It Doesn't. https://dspace.mit.edu/bitstream/handle/1721.1/48829/participationi nb1172brow.pdf? sequence $=1$.

[5] Hilton, R. W., 2008. Managerial Accounting. McGraw-Hill.

[6] Mahoney, T. A., Jerdee, T. H., \& Carroll, S. J., 1965. Development of Managerial Performance: A Research Approach. Southwestern Publishing Co.

[7] Mathis, R. L., \& John, H. J., 2013. Human Resource Management. South-Western College Publishing.

[8] Nouri, H., \& Parker, R. J., 1998. The Relationship between Budget Participation and Job Performance the Roles of Budget Adequacy and Organizational Commitment. Accounting Organization and Society, 23(5-6), 467-483.

[9] Robbins, S. P., 2008. Organizational Behavior: Concepts, Controversions, and Applications. Prehenlindo.

[10] Rosidah, S., \& Ambar, T., 2009, MSDM Konsep, Teori dan Pengembangan dalam Konteks Organisasi Publik. Graha Ilmu. 